\title{
Androgen- and Estrogen-Receptor Content in Spontaneous and Experimentally Induced Canine Prostatic Hyperplasia
}

\author{
John Trachtenberg, L. Louise Hicks, and Patrick C. Walsh, \\ The James Buchanan Brady Urological Institute, The Johns Hopkins Hospital, \\ Baltimore, Maryland 21205
}

\begin{abstract}
A B S T R A C T To gain insight into the mechanism by which steroidal hormones influence the development of canine prostatic hyperplasia, nuclear and cytosolic androgen- and estrogen-receptor content, as measured under exchange conditions by the binding of $\left[{ }^{3} \mathrm{H}\right] \mathrm{R} 1881$ (methyltrienolone) and $\left[{ }^{3} \mathrm{H}\right]$ estradiol, respectively, were quantitated in the prostates of purebred beagles of known age. In young dogs with spontaneously arising and experimentally induced (androstanediol plus estradiol treatment) prostatic hyperplasia, nuclear, but not cytosolic, prostatic androgen-receptor content was significantly greater than that determined in the normal prostates of age-matched dogs $(3,452 \pm 222$ and 4,035 $\pm 274 \mathrm{fmol} / \mathrm{mg}$ DNA vs. $2,096 \pm 364 \mathrm{fmol} / \mathrm{mg}$ DNA, respectively). No differences were observed between the androgen-receptor content of the normal prostates of young dogs and the hyperplastic prostates of old dogs. The cytosolic and nuclear estrogen-receptor content of spontaneously arising prostatic hyperplasia in both young and old animals was similar to that found in normal prostates. The administration of estradiol plus androstanediol to castrate dogs significantly increased the prostatic nuclear androgen-receptor content over that found in dogs treated only with androstanediol. This estradiol-associated increase in nuclear androgenreceptor content was accompanied by the development of benign prostatic hyperplasia.
\end{abstract}

Estradiol treatment of castrate dogs resulted in an increase in prostatic nuclear estrogen-receptor content, in the appearance of a putative prostatic cytosolic progesterone receptor, and in an alteration of the epithelium of the prostate to one characterized by squamous metaplasia. Treatment of castrate dogs with both estradiol and androstanediol resulted in a reduc-

Dr. Trachtenberg is a Fellow of the Medical Research Council of Canada.

Received for publication 15 October 1979 and in revised form 26 December 1979. tion in prostatic nuclear estrogen-receptor content, disappearance of the progesterone receptor, and loss of squamous metaplasia.

An increase in nuclear androgen-receptor content, thus, appears to be an important event in the development of both spontaneously arising and experimentally induced canine prostatic hyperplasia. The mechanism of androgen-estrogen synergism in the experimental induction of canine benign prostatic hyperplasia may be explained by estradiol-mediated increases in nuclear androgen-receptor content. Because androstanediol blocked certain estradiol-mediated events within the prostate, a negative feedback mechanism may exist in which the response of the canine prostate to estrogens is modulated by rising levels of androgen.

\section{INTRODUCTION}

The sensitivity of the canine prostate to androgens and estrogens is widely accepted. Canine prostatic hyperplasia, a common model for the study of the human disease, only develops in the presence of functioning testes $(1,2)$ and regresses after bilateral orchiectomy (3). It can be maintained or restored after castration by the administration of exogenous androgens $(3,4)$ and can be induced successfully in castrated young dogs with the administration of either dihydrotestosterone or androstanediol in combination with estradiol $(5,6)$. Biochemically, canine prostatic hyperplasia has been characterized by the accumulation of dihydrotestosterone in prostatic tissue in concentrations five times normal (7).

For biological action to occur, current concepts of steroid hormone action dictate the presence of specific receptor molecules (8). These molecules bind with high affinity to steroid hormones within the cytosol and are translocated to the nucleus where the cellular response is initiated. Both androgen and estrogen 
receptors have been identified and characterized within the canine prostate $(9,10)$.

Thus, if hormones do indeed play a role in the pathogenesis of canine prostatic hyperplasia, then the content of hormone receptors may add valuable insight into this process. Although this hypothesis has proved attractive to many investigators (11-13), the place of receptor proteins in the development of prostatic hyperplasia remains uncertain.

In this paper, we report our evaluation of the cytosolic and nuclear prostatic androgen- and estrogenreceptor content of healthy young purebred beagles of known age with and without prostatic hyperplasia and of old beagles of known age with hyperplasia. We have demonstrated that the content of nuclear, but not cytosolic, androgen receptors is elevated in young dogs with prostatic hyperplasia. Furthermore, we have demonstrated that a complex interaction exists between the various steroid receptors within the canine prostate.

\section{METHODS}

Animals. 27 healthy purebred male beagles of known age were purchased from Buckshire Fanns, Perkasie, Pa. The mean age \pm SEM of 23 young animals was $2.2 \pm 0.4 \mathrm{yr}$ and of 4 old dogs was $6.0 \pm 0.1 \mathrm{yr}$. Details of the procurement and treatment of these animals have been reported elsewhere (6). Briefly, all animals underwent initial laparotomy under intravenous sodium pentobarbital to determine the size of the prostate before treatment. The prostates were measured in three dimensions (dorsoventral, craniocaudal, and transverse), and the apparent volume was calculated by regarding the prostate as a cube. Weight was estimated by means of a nomogram: $\left(1 \mathrm{~g}\right.$ prostate is equivalent to $\left.1.53 \mathrm{~cm}^{3} ; r=0.99\right)$. Where prescribed, castration was done at the time of laparotomy via the abdominal incision, and both epididymides and testes were removed. All animals were allowed 1 mo for recovery (and involution of the prostate in castrated dogs) before initiation of treatments.

Steroids for injection were procured and prepared as reported in detail (6). Estradiol and androsterone were purchased from Steraloids, Inc. (Pawling, N. Y.). $5 \alpha$-Androstane$3 \alpha, 17 \beta$-diol (androstanediol) ${ }^{1}$ was prepared by sodium borohydride reduction of androsterone. Purity of the steroids was tested by thin-layer chromatography and high-pressure liquid chromatography. Androstanediol $(25 \mathrm{mg} / \mathrm{ml})$ was finely powdered and suspended in triolein (practical grade, Sigma Chemical Co., St. Louis, Mo.) and estradiol was dissolved $(0.25 \mathrm{mg} / \mathrm{ml})$ in triolein.

16 of the young dogs with normal prostates were castrated, divided into four groups, and treated with deep intramuscular injections of either $(a)$ androstanediol, $25 \mathrm{mg}$ three times per week, $(b)$ estradiol, $0.25 \mathrm{mg}$ three times per week, $(c)$ androstanediol and estradiol in the above doses, or $(d)$ triolein alone. Seven of the young dogs and all four old dogs served as intact controls and received injections of triolein three times per week for the duration of the experimental period. At the termination of the 4-mo treatment period, all animals were sacrificed and their prostates quickly re-

${ }^{1}$ Abbreviations used in this paper: androstanediol, $5 \alpha$ androstane- $3 \alpha, 17 \beta$-diol; BPH, benign prostatic hyperplasia. moved, trimmed of surrounding connective tissue, weighed, divided into segments according to a predetermined pattern, and frozen in liquid nitrogen with adjacent sections placed in formalin for histological analysis by a veterinary pathologist. The histological techniques and criteria for pathological classification have been described (6). All tissue for receptor analyses was stored under liquid nitrogen in a Union Carbide liquid nitrogen refrigerator (Union Carbide, Corp., New York).

Binding studies. Most of the tissues analyzed for receptor content were derived from either intact animals or castrated dogs treated with pharmacological doses of steroid. Because the prostates of these animals were felt to possess high levels of steroid, assays were designed to measure total occupied and unoccupied receptor sites (exchange assay). As previously reported in detail by Hawkins et al., ${ }^{2}$ maximum binding of [ $\left.{ }^{3} \mathrm{H}\right] \mathrm{R} 1881$ (methyltrienolone) to the canine prostatic androgen receptor was achieved at $4^{\circ} \mathrm{C}$ by $24 \mathrm{~h}$; and binding was stable for at least 20 additional h. Significantly less binding was observed at incubation temperatures of either 15 or $30^{\circ} \mathrm{C}$. Greater than $95 \%$ exchange of occupied receptor sites was achieved by $24 \mathrm{~h}$ at $4^{\circ} \mathrm{C}$. Maximum binding of $\left[{ }^{3} \mathrm{H}\right]$ estradiol to the estrogen receptor was achieved by $30 \mathrm{~min}$ at $30^{\circ} \mathrm{C}$; binding remained stable for at least $24 \mathrm{~h}$. Greater than $95 \%$ exchange of occupied receptor sites was obtained after incubation at $30^{\circ} \mathrm{C}$ for $20 \mathrm{~h}$. Although a similar degree of binding was observed at an incubation temperature of $4^{\circ} \mathrm{C}$, exchange at this temperature could not be demonstrated. Therefore, the incubation conditions used for the determination of androgenreceptor content were $24 \mathrm{~h}$ at $4^{\circ} \mathrm{C}$, and for estrogen-receptor content were $20 \mathrm{~h}$ at $30^{\circ} \mathrm{C}$. Representative saturation analyses of R1881, estradiol binding to prostatic (ytosol, or nuclear extract are shown in Figs. 1 and 2.

Preparation of cytosol and nuclear extract. Tissue frozen in liquid nitrogen was pulverized with a Thermovac tissue pulverizer (Thermovac Industries, Corp., Copiague, N. Y.). The powdered tissue was added to 8 vol of TEDG buffer (10 $\mathrm{mM}$ Tris, $1.5 \mathrm{mM}$ EDTA, $1 \mathrm{m.M}$ dithiothreitol, $10 \%$ [wt/vol] glycerol, pH $7.4,22^{\circ} \mathrm{C}$ ) and homogenized in an allglass Duall homogenizer (Kontes Glass Co., V'ineland, N. J.) for two 5-10-s periods (pestle speed $1,350 \mathrm{rpm}$ ) with a 60 -s $4^{\circ} \mathrm{C}$ cooling-off period between homogenizations. An alicjuot $(0.5 \mathrm{ml})$ was saved for DNA determination. The homogenate was then centrifuged at $800 \mathrm{~g}$ for $20 \mathrm{~min}\left(4^{\circ} \mathrm{C}\right)$. The resulting supernate was decanted and then further centrifuged at $104,000 \mathrm{~g}$ for $1 \mathrm{~h}$ at $4^{\circ} \mathrm{C}$ to yield the supernatant cytosol fraction. The nuclear myofibrillar pellet obtained from the $800 \mathrm{~g}$ centrifugation was washed in $5 \mathrm{vol}$ of TEDG buffer $(800 \mathrm{~g}, 15 \mathrm{~min})$ and resuspended in $8 \mathrm{vol}$ of TEDK buffer $(10 \mathrm{mM}$ Tris, 1.5 $\mathrm{mM}$ EDTA, $1 \mathrm{mM}$ dithiothreitol, $0.6 \mathrm{M} \mathrm{KCl}, \mathrm{pH} 7.4$ at $22^{\circ} \mathrm{C}$ ). This suspension was homogenized with a Polytron PT 10-35 ( $5 \mathrm{~s}$, setting 5 , Brinkman Instruments, Inc., Westbury, N. Y.) and centrifuged for $1 \mathrm{~h}$ at $4^{\circ} \mathrm{C}$ at $104,000 \mathrm{~g}$ to yield the supernatant nuclear extract. Protein concentrations of both cytosols and nuclear extracts were adjusted to $2-3 \mathrm{mg} / \mathrm{ml}$ by the addition of appropriate buffers.

Androgen-receptor assay. $200 \mu \mathrm{l}$ of either cytosol or nuclear extract was incubated in triplicate with $50-\mu l$ solutions of $\left[{ }^{3} \mathrm{H}\right] \mathrm{R} 1881$ to yield final labeled ligand concentrations of 0.14-20 nM for cytosol and 0.14-30 n.M for nuclear extract. A parallel set of incubations was carried out with identical labeled ligand concentrations in the presence of a 100 -fold molar excess of unlabeled R1881 ( $2 \mu \mathrm{M}$ for cytosol or $3 \mu \mathrm{M}$ for nuclear extract) to determine the amount of nonspecific binding.

${ }^{2}$ Hawkins, E. F., L. L. Hicks, J. Trachtenberg, and P. C. Walsh. Manuscript submitted for publication. 

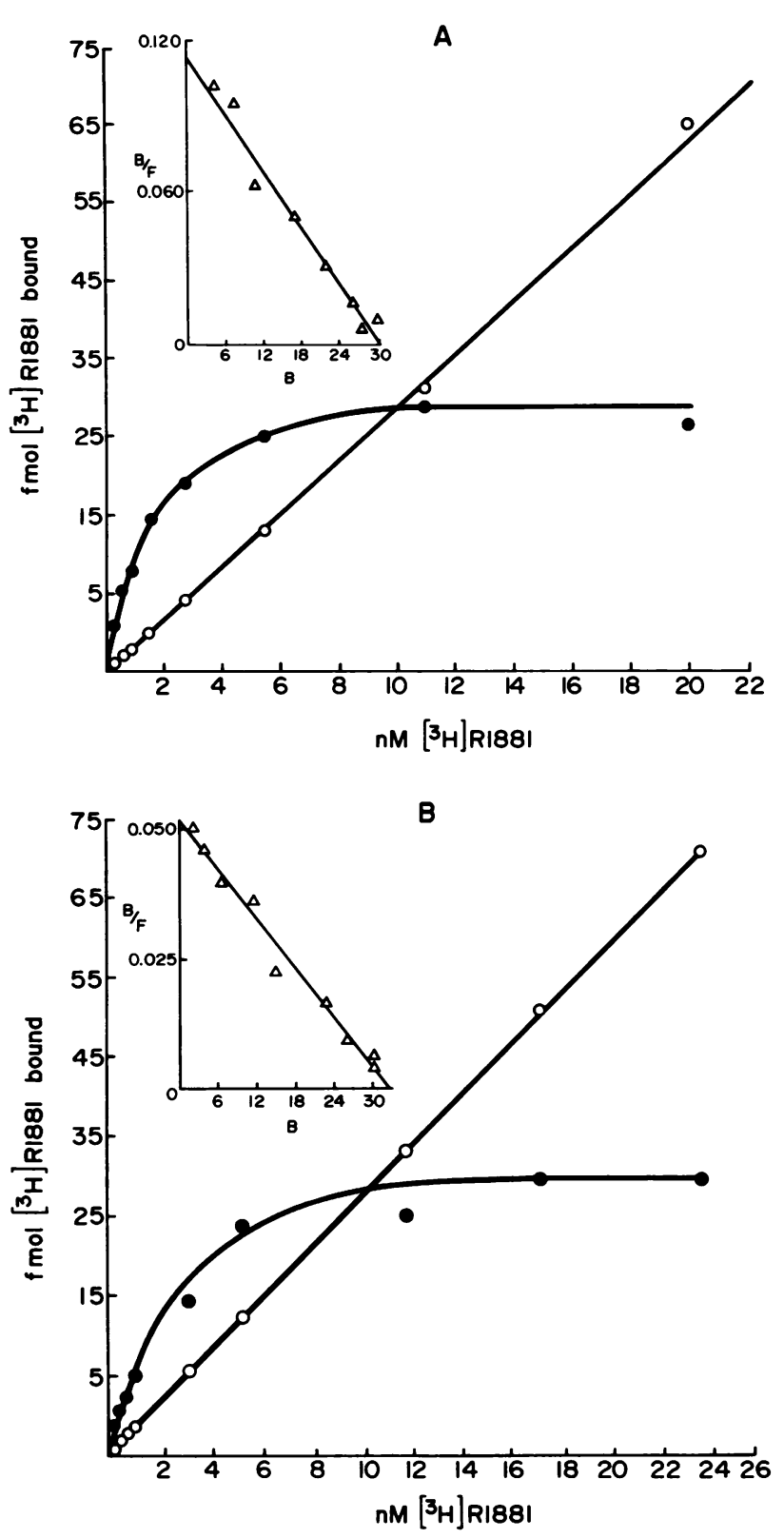

FIGURE 1 Saturation analysis of $\left[{ }^{3} \mathrm{H}\right] \mathrm{R} 1881$ binding to canine prostatic cytosol (A) and nuclear extract (B). Cytosol or nuclear extract was prepared and incubated in the presence of $\left[{ }^{3} \mathrm{H}\right] \mathrm{R} 1881$ alone or in combination with 100 -fold excess $\mathrm{R} 1881$ at $4^{\circ} \mathrm{C}$ for $24 \mathrm{~h}$. 0 , specific binding; $\bigcirc$, nonspecific binding. Data are also expressed in the form of a Scatchard plot. B, specifically bound steroid; F, free steroid.

After incubation at $4^{\circ} \mathrm{C}$ for $24 \mathrm{~h}, 500 \mu \mathrm{l}$ of a $0.25 \%$ dextrancoated charcoal suspension $(0.25 \%$ acid-washed activated charcoal, $0.0025 \%$ dextran, $10 \mathrm{mM}$ Tris, $1.5 \mathrm{mM}$ EDTA, $1 \mathrm{mM}$ dithiothreitol, $\mathrm{pH} 7.4,22^{\circ} \mathrm{C}$ ) was added to each assay tube, shaken on a rotary mixer at $140 \mathrm{rpm}$ for $15 \mathrm{~min}$, and then centrifuged at $5,000 \mathrm{~g}$ for $20 \mathrm{~min}$. The entire resulting supernate was then transferred to liquid scintillation vials, mixed in $10 \mathrm{ml}$ of ACS (Amersham/Searle Corp., Arlington Heights,
Ill.), and the radioactivity counted with an efficiency of $34 \%$. The data were analyzed by the method of Scatchard (14) and specific binding was expressed as femtomoles of steroid bound per milligram of cellular DNA for both cytosol and nuclear extract.

Estrogen-receptor assay. $200 \mu \mathrm{l}$ of either cytosol or nuclear extract was incubated in triplicate with $50-\mu l$ solu-
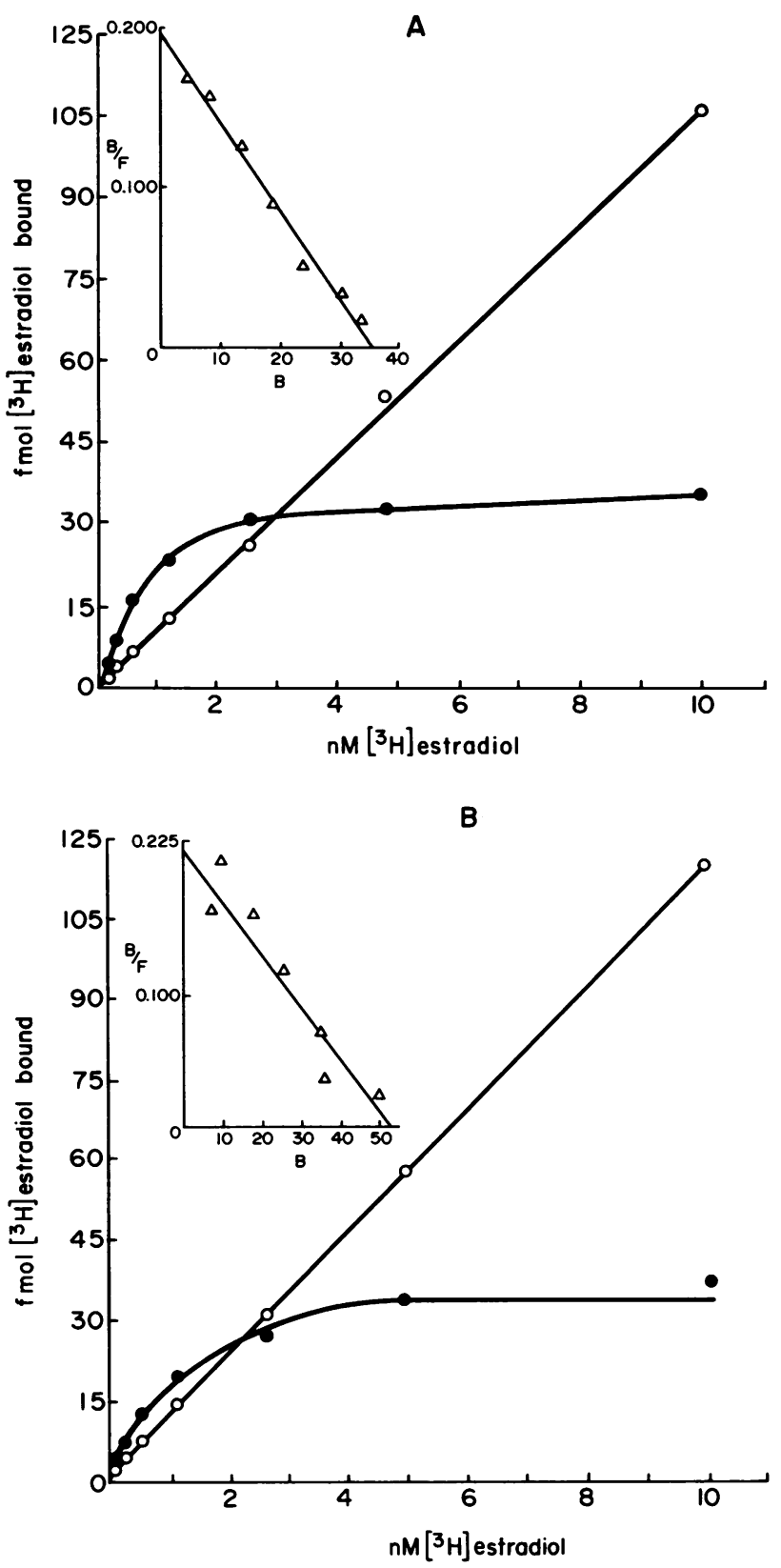

FIGURE 2 Saturation analysis of $\left[{ }^{3} \mathrm{H}\right]$ estradiol binding to canine prostatic cytosol (A) and nuclear extract (B). Cytosol or nuclear extract was prepared and incubated in the presence of $\left[{ }^{3} \mathrm{H}\right]$ estradiol alone or in combination with 100 -fold excess estradiol at $30^{\circ} \mathrm{C}$ for $20 \mathrm{~h}$. 9 , specific binding; $O$, nonspecific binding. Data are also expressed in the form of a Scatchard plot. $B$, specifically bound steroid; $F$, free steroid. 
tions of $\left[{ }^{3} \mathrm{H}\right]$ estradiol to yield final labeled ligand concentrations of 0.15-10 nM. A parallel set of incubations was carried out with identical labeled ligand concentrations in the presence of a 100-fold excess of unlabeled estradiol to determine the amount of nonspecific binding. After incubation at $30^{\circ} \mathrm{C}$ for $20 \mathrm{~h}$, free steroid was removed and specific binding was calculated and expressed as above.

Steroid specificity studies. $200 \mu \mathrm{l}$ of cytosol or nuclear extract was incubated in triplicate in the presence of $10 \mathrm{nM}$ $\left[{ }^{3} \mathrm{H}\right] \mathrm{R} 1881$ alone or in the presence of $50 \mathrm{nM}, 100 \mathrm{nM}$, or 1.0 $\mu \mathrm{M}$ unlabeled R1881 or progesterone. After incubation at $4^{\circ} \mathrm{C}$ for $24 \mathrm{~h}$ unbound and loosely bound steroid was removed with dextran-coated charcoal as described above; the amount of specifically bound $\left[{ }^{3} \mathrm{H}\right] \mathrm{R} 1881$ was calculated for each concentration of unlabeled competing steroid. The percent inhibition of specifically bound R1881 was then plotted against the molar excess of the competitor, and the amount required for $50 \%$ inhibition was determined. The ratio of the concentration of unlabeled R1881 to that of progesterone required for $50 \%$ inhibition, times $100 \%$, was termed the "relative binding affinity."

Protein and DNA measurements. Protein concentration was determined by measuring absorbances at 230 and $260 \mathrm{~nm}$ and correcting the values to milligrams per milliliter (A230 $\times 184)-($ A260 $\times 76.1)=$ protein in micrograms per milliliter (15).

DNA was measured by the method of Burton (16) using calf thymus DNA as standard.

Steroids. [17 $\alpha$-methyl $\left.{ }^{3} \mathrm{H}\right] \mathrm{R} 1881(87 \mathrm{Ci} / \mathrm{mmol})$ and $[2,4,6,7-$ $\left.{ }^{3} \mathrm{H}\right] 17 \beta$-estradiol $(96 \mathrm{Ci} / \mathrm{mmol}$ ), as well as their radioinert counterparts, were obtained from New England Nuclear (Boston, Mass.). All other radioinert steroids for binding studies were obtained from Steraloids, Inc.

\section{RESULTS}

At the termination of the 4-mo experimental period, all dogs were classified according to age, treatment, and the presence of prostatic hyperplasia. De Klerk et al. (6) recently reported that histological evidence of canine prostatic hyperplasia is uniformly present in beagle prostates weighing $>18 \mathrm{~g}$. Thus, using this gravimetric criterion and a histological classification of prostatic hyperplasia, all untreated beagles were assigned to either a "hyperplastic" or "normal" group. However, the above gravametric criterion does not hold for steroid-treated animals and, consequently, the development of prostatic hyperplasia in these animals was judged only on the basis of histological criteria (6).

Using the above criteria to define prostatic hyperplasia, three young intact (young benign prostatic hyperplasia [BPH]) and all four of the old intact (old BPH) dogs were found to have prostatic hyperplasia (Table I). Although the prostates of castrated untreated dogs uniformly displayed atrophic changes, those of estradiol-treated castrates were characterized by atrophy or squamous metaplasia (6). Squamous metaplasia was never observed in any of the other groups. Androstanediol treatment alone restored the castrate prostate to a normal histological appearance, whereas the combined treatment with androstanediol and estradiol treatment induced prostatic hyperplasia (6) (Table I).

Androgen receptor. Cytosol and nuclear androgenreceptor contents were measured in the prostates of intact dogs with normal prostates and those with spontaneously arising prostatic hyperplasia (Table II). High affinity binding of $\left[{ }^{3} \mathrm{H}\right] \mathrm{R} 1881$ was detected in all cases and no significant differences in apparent equilibrium dissociation constants were noted between groups (Table II). Although no differences were noted in cytosolic androgen-receptor content in any of the intact groups, the prostatic nuclear androgenreceptor content of young dogs with spontaneously arising BPH was significantly greater than that of normal prostates of age-matched dogs (Table II). The mean nuclear androgen-receptor content of old dogs with $\mathrm{BPH}$, although higher than that of normal young dogs, was not significantly different (Table II).

In castrated dogs, high affinity androgen binding was detected in all groups and there were no significant differences in the apparent dissociation constants between groups. In untreated castrate dogs, cytosolic and nuclear androgen-receptor levels were low. Treatment with androstanediol increased both cytosolic and nuclear androgen-receptor levels to those observed in young control dogs (Table II). Although prostatic weight was significantly increased to the weight normally seen in spontaneously developing BPH, histologically, the glands were normal (Table I). Treatment of castrated dogs with androstanediol and estradiol resulted in levels of cytosolic androgen receptor comparable with those found in dogs treated with androstanediol alone. Nuclear androgen-receptor levels, however, were significantly greater than those encountered with androstanediol treatment (Table II), and histological evidence of glandular hyperplasia was noted (Table I).

In castrated dogs treated with estradiol, cytosolic and nuclear androgen-receptor content, as measured by $\mathrm{R} 1881$ binding, very significantly increased over levels found in control castrate animals (Table II). It is well known that R1881 binds with high affinity to both the androgen and progesterone receptors $(17,18)$; in all other treatment groups, the steroid specificity of R1881 binding was characteristic for an androgen receptor (Table III). However, the relative binding affinity of progesterone for R 1881 binding sites in the cytosol of estradiol-treated castrates was $72 \pm 9 \%$ compared with an average of $3 \%$ in the other treatment groups (Table III). In our experience, the relative binding affinity of progesterone for R1881 binding to the androgen receptor in human and rat prostatic cytosol is $2-3 \%$, whereas the relative binding affinity to cytosol containing a progesterone-binding molecule averages $36 \%(18,19)$. Thus, these data sug- 
TABLE I

Histology and Weight of Beagle Prostates at the Termination of the Experimental Period

\begin{tabular}{|c|c|c|c|}
\hline Group & $\begin{array}{c}\text { Number of } \\
\text { dogs }\end{array}$ & Histology & $\begin{array}{l}\text { Mean prostatic } \\
\text { weight (average } \\
\quad \pm \text { SEM) }\end{array}$ \\
\hline & & & $g$ \\
\hline \multicolumn{4}{|l|}{ Untreated intact } \\
\hline Young control & 4 & Normal & $10.9 \pm 0.9$ \\
\hline Young BPH & 3 & $\begin{array}{l}\text { Glandular } \\
\text { hyperplasia }\end{array}$ & $22.3 \pm 2.1$ \\
\hline Old BPH & 4 & $\begin{array}{l}\text { Cystic or glandular } \\
\text { hyperplasia }\end{array}$ & $32.2 \pm 1.5$ \\
\hline \multicolumn{4}{|l|}{ Treated castrates } \\
\hline Control & 4 & Atrophy & $2.3 \pm 0.4$ \\
\hline Estradiol & 5 & $\begin{array}{l}\text { Atrophy or squamous } \\
\text { metaplasia }\end{array}$ & $6.7 \pm 0.4$ \\
\hline Androstanediol & 3 & Normal & $19.4 \pm 1.8$ \\
\hline $\begin{array}{l}\text { Androstanediol plus } \\
\text { estradiol }\end{array}$ & 4 & $\begin{array}{l}\text { Glandular } \\
\text { hyperplasia }\end{array}$ & $40.9 \pm 1.9$ \\
\hline
\end{tabular}

gested that treatment with estradiol may have induced a progesterone receptor in canine prostatic cytosol. Indeed, induction of a progesterone receptor by estrogen is well recognized in a variety of estrogensensitive tissues (20-23). Moreover, this finding of a putative progesterone receptor suggested that the estimation of androgen-receptor content in estradioltreated animals as measured by R1881 might be artifically high as a result of the presence of both androgen and progesterone receptors. To resolve this possibility, saturation analyses were performed using $\left[{ }^{3} \mathrm{H}\right] \mathrm{R} 1881$ alone or in combination with a $1,000-$ fold

TABLE II

Apparent Equilibrium Dissociation Constants and Quantities of R1881 Binding Sites in Intact and Steroid-treated Castrate Beagle Prostates*

\begin{tabular}{|c|c|c|c|c|}
\hline \multirow[b]{2}{*}{ Group } & \multicolumn{2}{|c|}{ Cytosol } & \multicolumn{2}{|c|}{ Nuclear extract } \\
\hline & Affinity & Binding sites & Affinity & Binding sites \\
\hline & $K_{d} \times 10^{9} . M$ & fmollmg DNA & $K_{d} \times 10^{9} M$ & fmol/mg DNA \\
\hline \multicolumn{5}{|l|}{ Untreated intact } \\
\hline Young control & $1.6 \pm 0.4$ & $1,121 \pm 141 \neq$ & $4.4 \pm 0.2$ & $2,096 \pm 364 \ddagger$ \\
\hline Young BPH & $1.6 \pm 0.4$ & $1,159 \pm 74 \ddagger$ & $4.9 \pm 0.6$ & $3,452 \pm 222 \ddagger \S$ \\
\hline Old BPH & $0.9 \pm 0.3$ & $1,152 \pm 264 \ddagger$ & $4.8 \pm 0.6$ & $3,174 \pm 817 \ddagger$ \\
\hline \multicolumn{5}{|l|}{ Treated castrates } \\
\hline Treatment control & $1.2 \pm 0.5$ & $133 \pm 58 \oint$ & $2.2 \pm 0.8$ & $223 \pm 6 \S$ \\
\hline Estradiol & $1.1 \pm 0.2$ & $1,242 \pm 259 q^{\prime \prime}$ & $2.5 \pm 0.3$ & $1,138 \pm 111 \neq \S "$ \\
\hline Androstanediol & $1.8 \pm 0.1$ & $1,529 \pm 333 \ddagger$ & $3.6 \pm 0.4$ & $2,000 \pm 358$ \\
\hline \multicolumn{5}{|l|}{ Androstanediol plus } \\
\hline estradiol & $2.2 \pm 0.2$ & $1,503 \pm 120 \ddagger$ & $3.2 \pm 0.3$ & $4,035 \pm 274 \ddagger \S$ \\
\hline
\end{tabular}

* Data are the mean \pm SEM. Apparent dissociation constant $\left(\mathrm{K}_{\mathrm{d}}\right)$ and receptor content were determined by saturation analysis employing $\left[{ }^{3} \mathrm{H}\right] \mathrm{R} 1881$ at $4^{\circ} \mathrm{C}$ for $24 \mathrm{~h}$.

$\ddagger$ Significantly different $(P<0.05)$ from the receptor content value of the untreated castrate dogs as determined by analysis of variance.

$\$$ Significantly different $(P<0.05)$ from the receptor-content value of the intact young control dogs as determined by analysis of variance.

"These values represent R1881 binding to both androgen receptor and progesterone receptor. See text. 
TABLE III

Relative Binding Affinity of Progesterone for R1881 Binding in Cytosol of Untreated Intact and Steroid-Treated Castrate Beagle Prostates

\begin{tabular}{lcc}
\hline \multicolumn{1}{c}{ Group } & $\begin{array}{c}\text { Number of } \\
\text { determinations }\end{array}$ & $\begin{array}{c}\text { Relative binding } \\
\text { affinity* }\end{array}$ \\
\hline $\begin{array}{l}\text { Intact untreated } \\
\text { (young control, 4; } \\
\text { young BPH, 3; } \\
\text { old BPH, 3) }\end{array}$ & $\%$ \\
$\begin{array}{l}\text { Castrate control } \\
\text { Castrate plus } \\
\quad \text { estradiol }\end{array}$ & 10 & $3 \pm 1$ \\
$\begin{array}{l}\text { Castrate plus } \\
\text { androstanediol } \\
\text { Castrate plus } \\
\text { androstanediol } \\
\text { plus estradiol }\end{array}$ & 2 & $3 \pm 3$ \\
\hline * Data are the mean \pm SEM of the number of determinations \\
$\begin{array}{l}\text { described in this table. } \\
\pm \text { Significantly different }(P<0.05) \text { from the other values. }\end{array}$
\end{tabular}

molar excess of triamcinolone acetonide. At this concentration, triamcinolone acetonide, a potent synthetic glucocorticoid that binds with high affinity to the progesterone receptor, inhibits binding of R1881 to the progesterone receptor without interfering with the high affinity binding of R1881 to the androgen receptor $(19,24)$. Because of limited availability of tissue, only one determination using triamcinolone acetonide was performed in prostatic tissue obtained from castrated dogs treated with estradiol. The addition of triamcinolone acetonide reduced $\left[{ }^{3} \mathrm{H}\right] \mathrm{R} 1881$-binding site concentrations by $57 \%$ in cytosol and $56 \%$ in nuclear extract, yielding a "true" androgen-receptor content of 404 and $435 \mathrm{fmol} / \mathrm{mg}$ DNA, respectively. These values are approximately twice the mean value of androgen-receptor content determined in castrate control animals. In castrate animals treated with both androstanediol and estradiol, the relative binding affinity of progesterone $(3 \pm 3 \%)$ gave no indication for the presence of a progesterone receptor. This was verified by simultaneous saturation analyses using $\left[{ }^{3} \mathrm{H}\right] \mathrm{R} 1881$ in the presence and absence of a 1,000-fold molar excess of triamcinolone acetonide. The number of binding sites in the absence and presence of triamcinolone acetonide was similar for both cytosol (1,691 and 2,195 fmol/mg DNA, respectively) and nuclear extract $(3,986$ and $4,541 \mathrm{fmol} / \mathrm{mg}$ DNA, respectively). Thus, prostatic androgen-receptor content as measured by $\left[{ }^{3} \mathrm{H}\right] \mathrm{R} 1881$ binding in castrate dogs treated with both androstanediol and estradiol is an accurate estimate of androgen-receptor levels. These values demonstrate a highly significant enhancement by estradiol of nuclear androgen-receptor content over that measured in dogs treated with androstanediol alone (Table II).

Estrogen receptor. High affinity estradiol binding was demonstrated reproducibly in the cytosols and nuclear extracts of all groups (Table IV). No differences in the apparent dissociation constants were detected between groups. In untreated intact dogs, no differences in cytosol or nuclear extract estrogen-receptor content were detected in any of the groups examined. Cytosolic estrogen-receptor contents in all of the steroidtreated castrate dogs were not different (Table IV). In untreated castrate dogs or castrate dogs treated with androstanediol, nuclear estrogen-receptor content was low. Estrogen therapy, as might be expected, markedly increased nuclear estrogen-receptor content over levels observed in untreated dogs. However, the nuclear estrogen-receptor content of those dogs treated with both androstanediol and estradiol was similar to the castrate control level (Table IV).

\section{DISCUSSION}

Shain and Boesel (11) have reported on the content of cytosolic and nuclear androgen receptors in normal and hyperplastic canine prostate. Because they found no significant differences in either the cytosolic or nuclear levels of androgen receptor, they concluded that prostatic hyperplasia was not a consequence of the proliferation of androgen receptors. Their studies, however, compared the normal prostate of young dogs with the classic hyperplasia of old dogs. In this report, we too have been unable to find any significant difference in the content of either nuclear or cytoplasmic androgen receptor in the normal prostates of young dogs or hyperplastic prostates of old dogs. Although the mean value of nuclear androgen-receptor content in old dogs was higher than that observed in young normal dogs, the marked variance of the receptor measurements in the old dogs precluded statistical significance. The reasons for this variance are unclear. Testosterone secretion by the testes of old dogs is decreased $^{3}$ and receptor measurements may mirror different stages in this decline in individual dogs. Furthermore, prostatic tissue in the old dog is heterogeneous, containing areas of atrophy and hyperplasia and areas of fluid-filled cysts. This increases the likelihood of sampling different tissue types in different animals. However, BPH is recognized to develop in young animals and has the histological characteristics of a predominantly hyperplastic epithelium (6). Consequently, young dogs with BPH provide a model for studying the disease in age-matched animals with homogeneous prostatic tissue. Also, by using young

\footnotetext{
${ }^{3}$ L. Ewing. Personal communication
} 
TABLE IV

Apparent Equilibrium Dissociation Constant and Quantities of Estradiol Binding Sites in Untreated Intact and Steroid-treated Castrate Beagle Prostates*

\begin{tabular}{|c|c|c|c|c|}
\hline \multirow[b]{2}{*}{ Group } & \multicolumn{2}{|c|}{ Cytosol } & \multicolumn{2}{|c|}{ Nuclear extract } \\
\hline & Affinity & Binding sites & Affinity & Binding sites \\
\hline & $K_{d} \times 10^{9} . M$ & fmol/mg DNA & $K_{t} \times 10^{9} . \mathrm{M}$ & fmollmg DNA \\
\hline \multicolumn{5}{|l|}{ Untreated intact } \\
\hline Young control & $0.5 \pm 0.3$ & $2,830 \pm 975$ & $1.1 \pm 0.2$ & $844 \pm 152$ \\
\hline Young BPH & $0.3 \pm 0.1$ & $2,192 \pm 141$ & $0.9 \pm 0.2$ & $1,124 \pm 236$ \\
\hline Old BPH & $0.7 \pm 0.1$ & $2,809 \pm 635$ & $1.3 \pm 0.2$ & $871 \pm 156$ \\
\hline \multicolumn{5}{|l|}{ Treated castrate } \\
\hline Treatment control & $0.5 \pm 0.1$ & $1,062 \pm 632$ & $0.6 \pm 0.0$ & $766 \pm 2$ \\
\hline Estradiol & $0.5 \pm 0.2$ & $1,597 \pm 357$ & $0.6 \pm 0.1$ & $2,251 \pm 299 \ddagger$ \\
\hline Androstanediol & $0.2 \pm 0.1$ & $2,044 \pm 63$ & $0.5 \pm 0.1$ & $447 \pm 282$ \\
\hline $\begin{array}{l}\text { Androstanediol plus } \\
\text { estradiol }\end{array}$ & $0.7 \pm 0.2$ & $1,627 \pm 430$ & $1.2 \pm 0.3$ & $621 \pm 102$ \\
\hline
\end{tabular}

\footnotetext{
* Data are the mean \pm SEM for at least three independent determinations except for the castrate control group that consisted of two determinations. Apparent dissociation constant $\left(\mathrm{K}_{\mathrm{d}}\right)$ and receptor content were determined by saturation analysis employing $\left[{ }^{3} \mathrm{H}\right]$ estradiol at $30^{\circ} \mathrm{C}$ for $20 \mathrm{~h}$.

I Significantly different $(P<0.05)$ from the receptor-content value of the castrate control dogs as determined by analysis of variance.
}

dogs with $\mathrm{BPH}$, one is able to investigate the disease at an active stage in its development (6).

The content of cytosolic androgen receptor in young normal and young hyperplastic prostates was not different. However, the content of prostatic nuclear androgen receptor was significantly greater in young dogs with prostatic hyperplasia than in age-matched animals with normal prostates. Similarly, castrate dogs treated with both androstanediol and estradiol in which prostatic hyperplasia was induced also showed an increase in nuclear but not cytosolic androgen-receptor content. Conversely, castrate young dogs that had been treated with androstanediol alone, and whose prostates were histologically normal, demonstrated androgenreceptor levels similar to those found in the intact normal prostate. Thus, an increase in nuclear but not cytosolic androgen-receptor content accompanies the occurrence of prostatic hyperplasia in the young dog.

Steroid hormones are believed to act only in the presence of specific receptor molecules and to exert their major influence within the nucleus (25). Clark et al. (26) have stated that in the rat uterus true growth only occurs in the presence of and after a specific retention period of the nuclear steroid-receptor complex. We believe that elements of the above concepts are operational in the canine prostate. Because the cytosol is both the site of origin of the receptor and the major destination of receptor leaving the nucleus $(25,27)$, then the constant cytosolic level of androgen receptor in the face of an elevated nuclear level of androgen receptor in hyperplastic prostates indicates nuclear accumulation of the steroid-receptor complex. This may be the result of increased cytoplasmic synthesis of receptor and subsequent nuclear translocation or a normal rate of production with decreased processing, thereby leading to nuclear accumulation $(28,29)$. In either case, the level of nuclear androgen receptor appears to correlate with the development of prostatic hyperplasia because in both spontaneously arising and experimentally induced prostatic hyperplasia nuclear androgen-receptor content was elevated, whereas, in intact animals with normal prostates and androstanedioltreated animals with histologically normal prostates, nuclear androgen-receptor content was not elevated. Thus, elevated nuclear but not cytosolic androgenreceptor content not only accompanies the development of canine prostatic hyperplasia, but may play a direct role in the pathogenesis of this entity.

The development of BPH and the presence of elevated nuclear androgen-receptor content cannot, however, be viewed solely as the result of prolonged androgenic stimulation. Castrate dogs treated for $4 \mathrm{mo}$ with androstanediol neither developed prostatic hyperplasia nor accumulated elevated levels of prostatic nuclear androgen receptor. The addition of estradiol to androstanediol therapy, however, uniformly resulted in both the development of BPH and increased nuclear androgen-receptor content. Estradiol, thus, appears to be able to enhance the androgenic activity of androstanediol. The mechanism of this interaction, however, is unclear. Moore et al. (13) have demonstrated that estradiol treatment of castrate dogs results in a 
twofold increase in cytosolic androgen-receptor content. Based on this observation, they have speculated that enhancement of androgen-receptor activity may be responsible for estradiol-androstanediol synergism in experimentally induced prostatic hyperplasia. This paper supports and expands this concept. In this study we have demonstrated that treatment with estradiol and androstanediol produces a twofold increase in the content of nuclear androgen receptor over that achieved by treatment with androstanediol alone, and that this increase in receptor content correlates well with the development of prostatic hyperplasia. Consequently, estrogen-induced augmentation of androgen-receptor content may explain the androgen-estrogen synergism in the experimental induction of BPH. Whether estrogens may play a similar role in the induction of the spontaneous disease remains to be determined.

Insight into the mechanism of action of estrogen in the canine prostate has been aided by the identification of a specific estrogen receptor (10). In this study, we have demonstrated that treatment of castrates with estradiol results in an increase in both cytosolic and nuclear estrogen-receptor content and in the appearance of a cytosolic progesterone receptor. The latter finding has also been reported recently by Dubé et al. (30). Furthermore, estrogen produces a marked change in the morphological organization of the prostate from a predominantly atrophic epithelium to one characterized by squamous metaplasia and fibromuscular stroma. When castrate dogs are treated with both estradiol and androstanediol, there is enhanced androgenic activity with a simultaneous inhibition of estrogenic expression. Thus, nuclear androgen-receptor content is sharply elevated in association with marked hyperplasia of the epithelium and, in the presence of these increased androgenic events, there is a reduction in nuclear estrogen-receptor content (from levels present in estradiol-treated (astrates), disappearance of the progesterone receptor, and loss of squamous metaplasia. The ability of androgen to block these estrogen-induced events has been demonstrated in other species. Treatment with androgens can block estrogen-induced increases in nuclear estrogen-receptor content in rat uterus (31) and estrogen induction of the progesterone receptor in the hamster kidney (32). These data suggest that a negative feedback mechanism may exist in which certain responses of the canine prostate to estrogen may be modulated by rising levels of androgen.

This paper demonstrates that increased nuclear androgen-receptor content is a characteristic of both spontaneously occurring and experimentally induced canine prostatic hyperplasia. Furthermore, in the experimentally induced disease, the administration of estrogen increases nuclear androgen-receptor content that appears instrumental in the development of prostatic hyperplasia. Moore et al. (33), using a similar experimental protocol, demonstrated increased tissue levels of dihydrotestosterone in the prostates of dogs with experimentally induced $\mathrm{BPH}$ and suggested that the accumulation of this androgen is the cause of canine prostatic hyperplasia. They, however, were unable to postulate a receptor mechanism as the mode of dihydrotestosterone action because the levels of dihydrotestosterone that they demonstrated were higher than those that would be expected to saturate androgen receptors (33).

However, using their value for dihydrotestosterone content in experimentally induced BPH (castrate animals treated with $75 \mathrm{mg}$ of androstanediol and $0.75 \mathrm{mg}$ of estradiol/wk, $4.4 \mathrm{ng} / \mathrm{g}$ or $15,200 \mathrm{fmol} / \mathrm{g}$ ) and converting our values for total cytosolic and nuclear androgen-receptor content of similarly treated animals to femtomoles per gram of tissue $(13,200 \mathrm{fmol} / \mathrm{g})$, we find an almost equimolar content of dihydrotestosterone and androgen receptor. Thus, although it remains to be determined whether accumulation of dihydrotestosterone or increased androgen receptor is the primary event in the induction of canine BPH, it seems clear that both factors, acting together, play an important role in the development of this disease.

\section{ACKNOWLEDGMENTS}

This investigation was supported by the National Cancer Institute, Department of Health, Education, and Welfare grant 5 R26 CA 16924-05, and by the National Institutes of Arthritis, Metabolism, and Digestive Diseases grant AM 19300.

\section{REFERENCES}

1. Schlotthauer, C. F. 1932. Observations on the prostate gland of the dog. J. Am. Vet. Med. Assoc. 81: 645-650.

2. Berg, O. A. 1958. Parenchymatous hypertrophy of the canine prostate gland. Acta Endocrinol. 27: 140-154.

3. Huggins, C., and P. J. Clark. 1940. Quantitative studies of prostatic secretion. II. The effect of castration and of estrogen injection on the normal and in the hyperplastic prostate gland of dogs. J. Exp. Med. 72: 747-761.

4. Jacobi, G. H., R. J. Moore, and J. D. Wilson. 1978. Studies on the mechanism of $3 \alpha$-androstanediol induced growth of the dog prostate. Endocrinology. 102: 6, 17481755 .

5. Walsh, P. C., and J. D. Wilson. 1976. The induction of prostatic hypertrophy in the dog with androstanediol. J. Clin. Invest. 57: 1093-1097.

6. DeKlerk, D. P., D. S. Coffey, L. L. Ewing, I. R. McDermott, W. G. Reiner, C. H. Robinson, W. W. Scott, J. D. Strandberg, P. Talalay, P. C. Walsh, L. G. Wheaton, and B. R. Zirkin. 1979. Comparison of spontaneous and experimentally induced canine prostatic hyperplasia. J. Clin. Incest. 64: 842-849.

7. Gloyna, R. E., P. K. Siiteri, and J. D. Wilson. 1970. Dihydrotestosterone in prostatic hypertrophy. II. The formation and content of dihydrotestosterone in the hypertrophic canine prostate and the effect of dihydrotestosterone in prostatic growth in the dog. J. Clin. Invest. 49: $1746-1753$.

8. Gorski, J., and F. Gannon. 1976. Current models of 
steroid hormone action: a critique. Annu. Rev. Physiol. 38: 425-450.

9. Boesel, R. W., R. W. Klipper, and S. A. Shain. 1977. Identification of limited capacity androgen binding components in nuclear and cytoplasmic fractions of canine prostate. Endocr. Res. Commun. 4: 71-84.

10. Chaisiri, N., Y. Valotaire, B. A. J. Evans, and C. G. Pierrepoint. 1978. Demonstration of a cytoplasmic receptor protein for estrogen in the canine prostate gland. J. Endocrinol. 78: 131-139.

11. Shain, S. A., and R. W. Boesel. 1978. Androgen receptor content of the normal and hyperplastic canine prostate. J. Clin. Invest. 61: 654-660.

12. Dubé, J. Y., R. R. Trembley, F. T. Dionne, and P. Chapdelaine. 1979. Binding of androgens in dog prostate cytosol and in plasma. J. Steroid Biochem. 10: 449-458.

13. Moore, J., J. M. Gazak, and J. D. Wilson. 1979. Regulation of cytoplasmic dihydrotestosterone binding in dog prostate. J. Clin. Invest. 63: 351-358.

14. Scatchard, G. 1949. The attraction of proteins for small molecules and ions. Ann. N. Y. Acad. Sci. 51: 660-672.

15. Kalk, V. F., and R. W. Bernlohr. 1975. A 260/230 method for the determination of protein concentration in the presence of nucleic acids. Fed. Proc. 34(3): 546. (Abstr.)

16. Burton, K. 1956. A study of the conditions and mechanism of the diphenylamine reaction for the colorometric estimation of deoxyribonucleic acid. Biochem. J. 62: 315-323.

17. Ojasoo, T., and J. P. Raynaud. 1978. Unique steroid congeners for receptor studies. Cancer Res. 38: 41864198.

18. Menon, M., C. E. Tananis, L. L. Hicks, E. F. Hawkins, M. G. McLoughlin, and P. C. Walsh. 1978. Characterization of the binding of a potent synthetic androgen, methyltrienolone, to human tissues. J. Clin. Invest. 61: 150-162.

19. Hicks, L. L., and P. C. Walsh. 1979. A microassay for the measurement of androgen receptor in human prostatic tissue. Steroids. 33:(4): 389-406.

20. Horwitz, K. B., and W. L. McGuire. 1977. Estrogen and progesterone: their relationship in hormone dependent breast cancer. In Progesterone Receptors in Normal and Neoplastic Tissues. W. L. McGuire, J. P. Raynaud, and E. E. Baulieu, editors. Raven Press, New York. 103-124.

21. Baulieu, E. E., A. Alberga, I. Jung, M. C. Lebeau, C. Mercier-Bodard, E. Milgrom, J. P. Raynaud, C. RaynaudJammet, H. Rochefort, H. Truong, and P. Robel. 1971. Metabolism and protein binding of sex steroids in target organs: an approach to the mechanism of hormone ac- tion. In Recent Progress in Hormone Research. E. B. Astwood, editor, Academic Press, Inc. New York. 27: 351-419.

22. Milgrom, E., L. Thi, M. Atger, and E. E. Baulieu. 1973. Mechanisms regulating the concentration and conformation of the progesterone receptor(s) in the uterus. $J$. Biol. Chem. 248: 6366-6374.

23. Horwitz, K. B., and W. L. McGuire. 1977. Progesterone and progesterone receptors in experimental breast cancer. Cancer Res. 37: 1733-1738.

24. Zava, D. T., B. Landrum, K. B. Horwitz, and W. L. McGuire. 1979. Androgen receptor assay with $\left[{ }^{3} \mathrm{H}\right]-$ methyltrienolone (R1881) in the presence of progesterone receptors. Endocrinology. 104(4): 1007-1012.

25. Baulieu, E. E. 1976. Intracellular receptors and hormone antagonists. In Hormones and Antihormone Action at the Target Cell. J. H. Clark, W. Klee, A. Lenitzki, and J. Wolff, editors. Abakon Verlagsgesellschaft, Berlin. 51-58.

26. Clark, J. H., E. J. Peck, J. W. Hardin, and H. Eriksson. 1978. The biology and pharmacology of estrogen receptor binding: relationship to uterine growth. In Receptors and Hormone Action. B. W. O'Malley and L. Birnbaumer, editors. Academic Press, Inc., New York. 2: 1-31.

27. Walters, M. R., and J. H. Clark. 1978. Cytosol and nuclear compartmentalization of progesterone receptor of the rat uterus. Endocrinology.103: 601-609.

28. Horwitz, K. B., and W. L. McGuire. 1978. Estrogen control of progesterone receptor in human breast cancer, correlation with nuclear processing of estrogen receptor. J. Biol. Chem. 253: 2223-2228.

29. Horwitz, K. B., and W. L. McGuire. 1978. Nuclear mechanisms of estrogen action, effects of estradiol and anti-estrogens on estrogen receptors and nuclear receptor processing J. Biol. Chem. 253: 8185-8191.

30. Dubé, J. V., R. Lesage, and R. R. Trembley. 1979. Estradiol and progesterone receptor in dog prostate cytosol. J. Steroid. Biochem. 10: 459-466.

31. Hsueh, A. J. W., E. J. Peck, and J. H. Clark. 1976. Control of uterine estrogen receptor levels by progesterone. Endocrinology. 98: 438-444.

32. Li, S. A., and J. J. Li. 1978. Estrogen-induced progesterone receptor in the Syrian hamster kidney. I. Modulation by anti-estrogens and androgens. Endocrinology. 103: 2119-2128.

33. Moore, R. J., J. M. Gazak, J. F. Quebbeman, and J. D. Wilson. 1979. Concentration of dihydrotestosterone and $3 \alpha$-androstanediol in naturally occurring and androgeninduced prostatic hyperplasia in the dog. J. Clin. Invest. 64: $1003-1010$. 